\title{
Utilization of Instructional Materials in Teaching Chemistry in Senior Secondary Schools in Katsina Metropolis
}

\author{
Yazid, Rumah Lawal*; Abdulmumin, Abdulsalam Rumah; Jamilu, Amadi
}

Faculty of Education, Department of Education, Uumaru Musa Yar'adua University Katsina, Katsina State, Nigeria

* Corresponding Author

The research is financed by Asian Development Bank. No. 2006-A171(Sponsoring information)

\begin{abstract}
This study investigated the Utilization of Instructional Materials in Teaching Chemistry in Senior Secondary Schools in Katsina metropolis. The study was conducted with three research objectives, three research questions and three null hypotheses. The study adopted survey research design and used questionnaire and checklist as instrument for data collection. The sample for the study was arrived at using random sampling technique, hence the total of twenty four (24) chemistry teachers and three hundred and seventy (370) students were used as research sample. The analysis of the data collected was done using both descriptive and inferential statistics. Findings among others shows that: there is no significant difference in the availability of instructional materials for teaching chemistry in senior secondary schools in Katsina metropolis as the observed p value 0.310 is greater than the alpha value $(p=0.310>0.05)$, and that there is a significant difference in the utilization of instructional materials in teaching chemistry in senior secondary schools in Katsina metropolis as the observed p value 0.027 is less than the alpha value $(p=0.027<0.05)$. It is recommended that adequate instructional materials for teaching of chemistry in senior secondary schools in Katsina metropolis should be provided by the ministry of education and that teachers should improvise where instructional materials are not available to teach chemistry in the senior secondary schools in Katsina metropolis, among others.
\end{abstract}

Keywords - China insurance industry, Foreign fund, Challenge.

\section{INTRODUCTION}

Instructional materials are objects or devices that help the teacher to make learning meaningful to the learners Ikerionwu (2000). The importance of instructional materials in enhancing effective teaching and learning of science, chemistry in particular cannot be undermined due to positive impact it has on students' performance. Instructional materials assist the teacher to achieve the stated goals and objectives. Instructional materials of all kind appeal to the sense organs during teaching and learning Agina-Obu (2005). Instructional materials which are educational inputs are of vital importance to teaching of any subject in the school curriculum.

In his own perspective, Abdu-Raheem (2014) acknowledged that instructional materials are used by teachers to aid explanations and make learning of subject matter understandable to students during teaching and learning process. Instructional materials are essential and significant tools need for teaching and learning to promote teacher's efficiency and capture the student's attention in classroom situation. Kochhar (2012) supported that instructional materials are very significant learning and teaching tools. He suggested there is need for teachers to find necessary materials for instruction to supplement what textbook provide in order to broaden concepts and arouse student's interests in the subject. Fadeiye (2005) saw instructional materials as visual and audio-visual aids, concrete or non concrete, used by teachers to improve the quality of teaching and learning activities.

However, Akinleye (2010) attested that effective teaching and learning requires a teacher to teach the student with instructional materials and use practical activities to make learning more vivid, logical, realistic and pragmatic. Despite the fact that instructional materials are essential tools that can make learning, practical and knowledge acquisition easier they are not readily available in Nigerian 
secondary schools leading to low level of performance of learners in government examinations. This prompted the researcher to embark on this research whose focus is to survey the utilization of instructional materials in teaching chemistry in srnior secondary schools in Katsina metropolis.

Instructional materials make teaching and learning more meaningful, understandable and easy. But in spite of the benefits of instructional materials to teaching and learning, the scarcity and inadequate utilization of the instructional materials has hindered, to some extent, the efficiency of teaching and learning of chemistry. Instructional materials make learning meaningful and help to improve students' academic achievement. However these advantages of instructional materials have not reflected in the education system because of the dearth of these instructional materials in our schools. Most of the teachers do not even care to use instructional materials, they only depend on the old traditional method. This problems lead to students' massive failure in chemistry examinations, especially the school leaving certificate examination. Also Nov/Dec result of 2014 indicates that 51.62 percent out of 28,250 candidates who sat for chemistry passed with credit, indicating only half of the candidates passed with credit in chemistry that year.

It is in view of the above discussion, the researcher intended to embark on a survey research whose attention focuses on utilization of instructional materials in teaching chemistry in senior secondary schools in Katsina metropolis.

\section{THE OBJECTIVES OF THIS STUDY}

1. Find out the availability of instructional materials in teaching chemistry in senior secondary schools in Katsina metropolis.

2. Find out the extent of utilization of instructional materials in teaching chemistry in senior secondary schools in Katsina metropolis.

3. Find out the difference in the utilization of instructional materials between male and female teachers in teaching chemistry in senior secondary schools in Katsina metropolis.

This research project is expected to contribute positively in the areas of knowledge expansion, utilization of instructional materials towards effective teaching and learning chemistry. This would be significant to all stake holders in education such as, educational administrators, teachers, students, ministry of education and the society at large in identifying educational problems and challenges, there by coming up with possible solution and strategies to these problems.

\section{RESEARCH METHODOLOGY}

The research design adopted for this study is descriptive survey method. The survey method is adopted because the research involved collecting data from teachers and students hence, make generalization. The design is considered appropriate because it is thought to be such a design that will enable the researcher in identifying the characteristics of the phenomena under study through administration of questionnaires and working by checklist of instructional materials. Survey method is a method characterized by the selection of random sample from a large and small population in order to obtain empirical knowledge of contemporary nature.

\subsection{Research Population}

The population for this study stands at 10,520 students offering chemistry in public senior secondary schools in Katsina metropolis. And 24 Chemistry teachers in public senior secondary schools in Katsina metropolis. Thus the population of the study with respect to chemistry students is summarized in the table below;

Table 1. List of Schools and Their students' Population.

\begin{tabular}{|c|c|c|c|c|c|}
\hline$\overline{\mathbf{S} / \mathbf{N}}$ & Schools & SS1 & SS2 & SS3 & Total \\
\hline 1. & Dikko College Katsina & 181 & 205 & 161 & 547 \\
\hline 2. & Family Support Secondary School Katsina & 99 & 72 & 102 & 273 \\
\hline 3. & Government College Katsina, Day Wing & 401 & 465 & 281 & 1147 \\
\hline 4. & Government Girls College Senior Katsina & 290 & 229 & 232 & 751 \\
\hline
\end{tabular}




\begin{tabular}{|c|c|c|c|c|c|}
\hline 5. & Government Secondary School Dutsin-Safe & 139 & 118 & 62 & 319 \\
\hline 6. & Government Senior Secondary School K/Kaura & 263 & 365 & 388 & 1016 \\
\hline 7. & Government Senior Secondary School K/Yandaka & 690 & 401 & 264 & 1355 \\
\hline 8. & Government School For the Blind Katsina & 97 & 95 & 97 & 608 \\
\hline 9. & Government Pilot Senior Secondary School K/Sauri & 719 & 712 & 621 & 2052 \\
\hline 10. & Katsina College Katsina Senior & 410 & 441 & 489 & 1340 \\
\hline 11. & Sir Emeka Offer Senior Sec. School Kambarawa & 330 & 281 & 239 & 850 \\
\hline 12. & Sir Usman Nagogo College of Arabic and Islamic Studies & 242 & 182 & 163 & 587 \\
\hline & Total & 3855 & 3566 & 3099 & 10520 \\
\hline
\end{tabular}

(Source: Zonal Education Quality Assurance Office, Katsina Zone 2017)

Table 2. Population of Chemistry teachers with respect to school

$\mathbf{S} / \mathbf{N}$

Schools

Number of teachers

1. Dikko College Katsina

2. Family Support Sec. School Katsina

3. Government College Katsina Day Wing

4. Government Girls College Senior Katsina

5. Government Secondary School Dutsin-Safe

6. Government Senior Secondary School K/Kaura

7. Government Senior Secondary School K/Yandaka

8. Government School For the Blind Katsina

2

9. Government Pilot Senior Secondary School K/Sauri 
11. Sir Emeka Offer Senior Sec. School Kambarawa

12. Sir Usman Nagogo College of Arabic And Islamic Studies
4

1

(Source: Zonal Education Quality Assurance Office, Katsina Zone 2017)

3.2 Sample and Sampling Techniques

To determine sample size appropriate for this study, the researcher first consulted Research Advisers (2006) table of sample, keeping in mind the total population size of the students $(10,520)$.
The table suggests that a population size of 10,000 should have sample size of 370 . The table also equally suggest that for a population size of (24), the sample size shall be (20). Random sampling technique was used in selecting the schools.

Table 3. Sampled Schools

\section{S/N School}

Students' population

\section{Number of sampled students}

1. GSSS K/Yandaka

2. GSSS K/Kaura

3. Sir Usman Nagogo College of

Arabic and Islamic Studies

However, in the case of teacher-respondents; looking at the number of chemistry teachers (24) in senior secondary schools in Katsina metropolis, the researcher decided to include all the chemistry teachers found in the sampled schools.

3

$\cdot$

3

$\mathbf{R}$

e

$\mathbf{s}$

e

a

$\mathbf{r}$

c

h

\section{I}

$\mathbf{n}$

$\mathbf{s}$

$\mathbf{t}$

r

$\mathbf{u}$

m

e

n

t

S

The instrument used for this study was questionnaire and checklist constructed by the researcher which was subjected to validity. The researcher used two sets of questionnaire; one set for students, and one for teachers. Both the teachers' questionnaires and students' questionnaires contained fifteen (15) items each; and are designed on a five-point Likert scale (comprising of 
Strongly Agree, Agree, Undecided, Disagree and Strongly Disagree) in order to supply data as regards teachers and students opinions on the utilization of instructional materials in teaching chemistry in senior secondary schools in Katsina metropolis.

The (25) item checklist contained some instructional materials and equipment in teaching chemistry. The checklists are intended to assist the researcher in appropriately taking the inventory of and cross checking the available instructional materials and equipments in senior secondary schools in Katsina metropolis.

\subsection{Validity of the Instruments}

A measuring instrument is considered valid only when it measures truly and accurately what it intends to measure. In this case, content and face validity of the instrument was determined by lecturers in the Department of Education of Umaru Musa Yar'adua University for validation. Meanwhile, all corrections and modifications suggested by the validators are to be effected.

\subsection{Pilot Testing for Reliability of the Instruments}

Further to the validation of the instrument, the researcher conducted a pilot study on 50 senior secondary students of Albarka Secondary Schools (which is not part of the population of the study and not among the sample) and computed split-half reliability (reliability of internal consistency). To do so the researcher systematically split the scores obtained into two equal halves using odd and even number position of the items. The corresponding two set of scores obtained were then correlated using Pearson product moment correlation method. The $r$ value obtained was

0.52 which indicates the reliability of the half test, the $\mathbf{r}$ value was then substituted into the spearman's brown formula to obtain the reliability of the full test. The $\mathbf{R}$ value obtain was 0.68 indicating strong reliability of the instrument.

3.6 Procedure for Data Collection

The teachers' questionnaires and students' questionnaires were self-administered by the researcher in all the three sampled schools. Again, the checklists was also used by the researcher in taking down the availability of equipment and materials in the sampled schools.

The researcher also asked for the assistance of teachers to assist in administering the questionnaires to the students. In order to administer the instrument appropriately, systemically sampling technique was employed by the used of the class register, the researcher sampled out students by which their number ends with even number. Explanation was equally done by the researcher on how to respond to the questionnaire before students were asked to respond to the items on the questionnaire. Teacher's questionnaire was administer to them in the staff rooms. The researcher instantly collected back the scripts upon the completion of filling the instruments.

\subsection{Procedure for Data Analysis}

The data to be obtained are merely responds which will be converted to numbers, which may be meaningless if not reduced to usable and meaningful form. In terms of answering research questions, the researcher decided to employ descriptive statistics. While for testing hypotheses Ho1 and Ho2 analysis of variance ANOVA would be employ, while for Ho3 t-test independent sample would be employ for determining significant differences between two set of variables or phenomena. This is because the task involves the analysis of data from fairly large sample size of respondents. More also, the data collected is a nominal data and a continuous data and not a discrete one, in which case a non-parametric tool is the best.

\section{RESULTS \& DISCUSSIONS}

\subsection{Presentation of Data}

The data collected for this research is presented and analyzed using statistical package for social science SPSS in order to answer the research question and test the hypothesis with a view of knowing the utilization of instructional materials in teaching chemistry in senior secondary schools in Katsina metropolis, thus the data collected is presented in the following ways:

\subsection{Data Analysis}

Table 4. showing the availability of Instructional materials in SUNCAIS

$\begin{array}{lrrr}\mathrm{S} / \mathrm{N} & \text { Name of equipment/material } & \text { Absent } & \text { Present } \\ \text { Confirmed } & \text { Number } & & \end{array}$

1. Teachers' preparatory office

Yes 
2. Charts

3. Conical flasks

4. Tripod and retort stand

5. Test tubes

6. Watch glasses

7. Bunsen burner

8. Funnels

9. Graduated cylinders

10. Volumetric flasks

11. Droppers

12. $25 \mathrm{~cm}^{3}$ pipette

13. Burette

14. Ring stands, rings, and clamps

15. Tongs and forceps

16. Spatulas

17. Weighing balance

18. Petridish

19. Reagent bottles

20. Test tube rack

21. Beaker

22. Thermometer

23. Blue litmus paper

24. Red litmus paper

25. Filter paper

Yes 3

Yes $\quad 30$

Yes 20

Yes $\quad 30$

Yes

Yes

$\begin{array}{ll}\text { Yes } & 20 \\ \text { Yes } & 10 \\ \text { Yes } & 20 \\ \text { Yes } & 10 \\ \text { Yes } & 25 \\ \text { Yes } & 23 \\ \text { Yes } & 13 \\ \text { Yes } & 11 \\ \text { Yes } & 7 \\ \text { Yes } & 3 \\ \text { Yes } & 17 \\ \text { Yes } & 21 \\ \text { Yes } & 7 \\ \text { Yes } & 27 \\ \text { Yes } & 4 \\ \text { Yes } & 4 \text { packs } \\ \text { Yes } & 4 \text { packs } \\ \text { Yes } & 5 \text { packs }\end{array}$

From the above data collected from the check list it can be seen that all the 25 instructional materials are available in SUNCAIS with the exception of watch glasses and Bunsen burners.

Table 5. showing the availability of instructional materials in GSSS K/KAURA

$\begin{array}{lrrr}\mathrm{S} / \mathrm{N} & \text { Name of equipment/material } & \text { Absent } & \text { Present } \\ \text { Confirmed } & \text { Number } & & \end{array}$

1. Teachers' preparatory office

$\begin{array}{ll}\text { Yes } & 2 \\ \text { Yes } & 2 \\ \text { Yes } & 30 \\ \text { Yes } & 30 \\ \text { Yes } & 20 \\ \text { Yes } & 10 \\ \text { Yes } & 15 \\ \text { Yes } & 16\end{array}$


9. Graduated cylinders

10. Volumetric flasks

11. Droppers

12. $25 \mathrm{~cm}^{3}$ pipette

13. Burette

14. Ring stands, rings, and clamps

15. Tongs and forceps

16. Spatulas

17. Weighing balance

18. Petridish

19. Reagent bottles

20. Test tube rack

21. Beaker

22. Thermometer

23. Blue litmus paper

24. Red litmus paper

25. Filter paper
Yes

$\begin{array}{ll}\text { Yes } & 15 \\ \text { Yes } & 5 \\ \text { Yes } & 20 \\ \text { Yes } & 20 \\ \text { Yes } & 20 \\ \text { Yes } & 5 \\ \text { Yes } & 12 \\ \text { Yes } & 1 \\ \text { Yes } & 10 \\ \text { Yes } & 20 \\ \text { Yes } & 4 \\ \text { Yes } & 20 \\ \text { Yes } & 11 \\ \text { Yes } & 4 \text { packs } \\ \text { Yes } & 4 \text { packs } \\ \text { Yes } & 5 \text { packs }\end{array}$

From the above data collected from the check list it can be seen that all the 25 instructional materials are available in G.S.S.S K/Kaura. With the exception of graduated cylinders.

Table 6. showing the availability of instructional materials in GSSS K/YANDAKA

\begin{tabular}{llll}
$\begin{array}{l}\text { S/N } \\
\text { Confirmed }\end{array}$ & \multicolumn{1}{c}{$\begin{array}{c}\text { Name of equipment/material } \\
\text { Number }\end{array}$} & Absent & Present \\
\cline { 2 - 4 } 1. & Teachers' preparatory office & Yes & 2 \\
2. & Charts & Yes & 15 \\
3. & Conical flasks & Yes & 30 \\
4. & Tripod and retort stand & Yes & 15 \\
5. & Test tubes & Yes & 10 \\
6. & Watch glasses & Yes & 3 \\
7. & Bunsen burner & Yes & 1 \\
8. & Funnels & Yes & 20 \\
9. & Graduated cylinders & Yes & 5 \\
10. & Volumetric flasks & Yes & 3 \\
11. & Droppers & Yes & 10 \\
12. & 25cm 3 pipette & Yes & 12 \\
13. & Burette & Yes & 20 \\
14. & Ring stands, rings, and clamps & Yes & 13 \\
15. & Tongs and forceps & Yes & 2 \\
16. & Spatulas & Yes &
\end{tabular}


17. Weighing balance

18. Petridish

19. Reagent bottles

20. Test tube rack

21. Beaker

22. Thermometer

23. Blue litmus paper

24. Red litmus paper

25. Filter paper

$\begin{array}{ll}\text { Yes } & 1 \\ \text { Yes } & 5 \\ \text { Yes } & 20 \\ \text { Yes } & 5 \\ \text { Yes } & 28 \\ \text { Yes } & 8 \\ \text { Yes } & 5 \text { packs } \\ \text { Yes } & 7 \text { packs } \\ \text { Yes } & 4 \text { packs }\end{array}$

From the above data collected from the check list it can be seen that all the 25 instructional materials are available in G.S.S.S K/Yandaka.

To adequately answer the research question a table of percentage on the availability of instruction materials in the 3 schools was computed as follows;

Table 7. showing the percentage of availability of instructional materials.

\begin{tabular}{llcc}
\cline { 2 - 3 } S/N & Schools & \% Available & \% Unavailable \\
\hline 1. & SUNCAIS & $92 \%$ & $8 \%$ \\
2. & GSSS K/Kaura & $96 \%$ & $4 \%$ \\
3. & GSSS K/Yandaka & $100 \%$ & $0 \%$ \\
& TOTAL & $96 \%$ & $4 \%$
\end{tabular}

From table 7, above, it is clear that the percentage of the available equipment and material in the three schools is $96 \%$, On the other hand, the percent of the unavailable equipment and materials in the three schools is $4 \%$.

Meanwhile to answer this research question; all the 25 listed instructional materials are adequately available in the senior secondary schools of Kasina Metropolis with the exception Bunsen burner, graduated cylinder and watch glasses.

Table 8. Responses of students on utilization of instructional materials in teaching chemistry

S/N ITEM SA

A $\mathbf{U}$

DA

SD

1. Our chemistry laboratory is adequately utilized in $13.24 \%$ teaching chemistry.

2. Our chemistry teacher use Periodical

$28.11 \% \quad 4.95 \%$

$0 \%$

$10.81 \%$

$64.28 \%$

$56.49 \%$ 
charts during chemistry lesson.

3. Our chemistry teacher use

$\begin{array}{lllll}7.03 \% & 1.89 \% & 1.08 \% & 59.2 \% & 30.81 \%\end{array}$

Graphical materials (map and charts)

during chemistry lesson.

Volumetric flask is adequately utilized

In teaching chemistry

5. Weighing balance is adequately utilized

in teaching chemistry.

6. Conical flasks are adequately utilized

in teaching chemistry.

7. Test tubes and racks are adequately

utilized in teaching chemistry.

8. Burettes are adequately utilized in teaching chemistry.

9. Pipettes are adequately utilized

$13.24 \%$

$3.51 \%$

$2.97 \%$

$31.89 \%$

$48.38 \%$

$2.97 \%$

$0.81 \%$

$1.08 \%$

$14.04 \%$

$81.08 \%$

$2.16 \%$

$5.4 \%$

$0 \%$

$16.21 \%$

$76.22 \%$

$0.81 \%$

$4.59 \%$

$0 \%$

$56.49 \%$

$28.11 \%$

$0.54 \%$

$5.95 \%$

$1.35 \%$

$13.51 \%$

$78.64 \%$

in teaching chemistry.

10. Measuring cylinders are adequately

$0 \%$

$0.27 \%$

$0 \%$

$4.3 \%$

$95.4 \%$

utilized in teaching chemistry.

11. Heat sources such as Bunsen burner

$6.48 \%$

$2.97 \%$

$0.54 \%$

$72.97 \%$

$17.08 \%$

$1.08 \%$

$0.27 \%$

$0.54 \%$

$2.97 \%$

$95.14 \%$

nd portable burner are adequately utilized in our chemistry laboratory.

12. Beakers are adequately utilized in our

$0 \%$

$0 \%$

$0 \%$

$2.16 \%$

$97.84 \%$

Chemistry teachers improvise instructional materials and equipment during chemistry lessons.

$\begin{array}{lllll}0.54 \% & 0.27 \% & 0 \% & 1.08 \% & 98.11 \%\end{array}$

\section{AVERAGE}

$6.63 \%$

$2.61 \%$

$\mathbf{0 . 8 1 \%}$

$24.42 \%$

$64.89 \%$

From the tables above, it is clear that majority of the students (64.89\%) strongly disagreed and

$24.42 \%$ disagreed with the fact that chemistry teachers adequately utilize instructional materials in teaching chemistry in the schools under study.

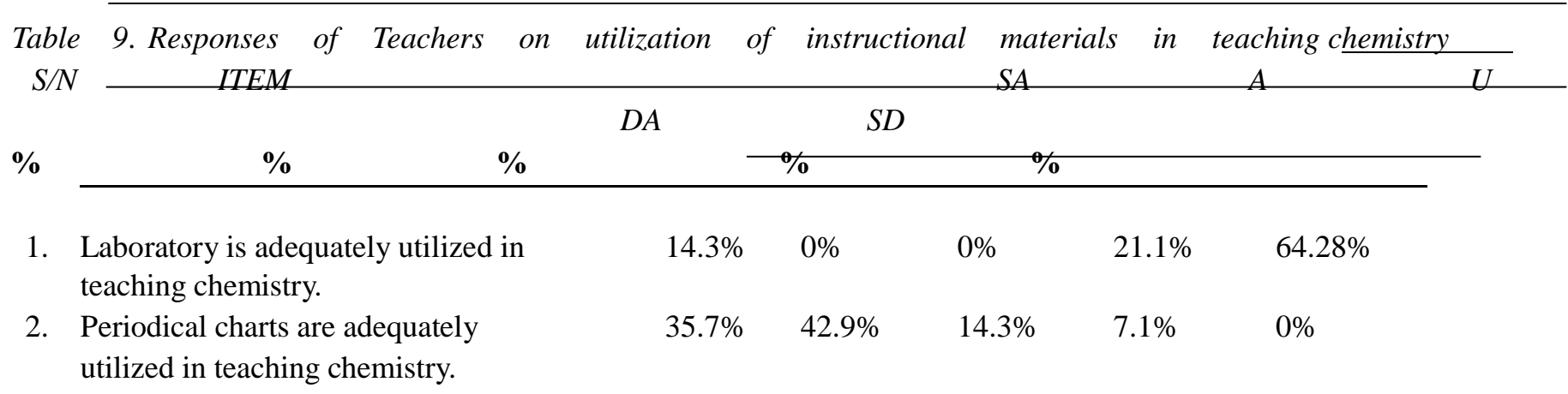


3. Graphical materials (map and charts) are adequately utilized in teaching chemistry.

4. Volumetric flask is adequately utilized in teaching chemistry

5. Weighing balance is adequately utilized in teaching chemistry.

6. Conical flasks are adequately utilized in teaching chemistry.

7. Test tubes and racks are adequately utilized in teaching chemistry.

8. Burettes are adequately utilized in teaching chemistry.

9. Pipettes are adequately utilized in teaching chemistry.

10. Measuring cylinders are adequately utilized in teaching chemistry.

11. Heat sources such as Bunsen burner and portable burner are adequately utilized in our chemistry laboratory.

12. Beakers are adequately utilized in our chemistry laboratory.

13. Chemistry teachers improvise $0 \%$

instructional materials and equipment during chemistry lessons.

$7.1 \%$

$\begin{array}{lllll}14.3 \% & 21.1 \% & 7.1 \% & 28.6 \% & 28.6 \%\end{array}$

$\begin{array}{lllll}42.9 \% & 0 \% & 0 \% & 7.1 \% & 50 \%\end{array}$

$\begin{array}{lllll}14.3 \% & 7.1 \% & 0 \% & 35.7 \% & 42.9 \%\end{array}$

$\begin{array}{lllll}64.28 \% & 21.1 \% & 0 \% & 0 \% & 14.3 \%\end{array}$

$\begin{array}{lllll}50 \% & 42.9 \% & 7.1 \% & 0 \% & 0 \%\end{array}$

$\begin{array}{lllll}0 \% & 0 \% & 0 \% & 42.9 \% & 57.1 \%\end{array}$

$\begin{array}{lllll}78.6 \% & 0 \% & 0 \% & 7.1 \% & 14.3 \%\end{array}$

$\begin{array}{lllll}0 \% & 0 \% & 7.1 \% & 7.1 \% & 85.71 \%\end{array}$

$\begin{array}{lllll}14.2 \% & 7.1 \% & 0 \% & 21.1 \% & 87.1 \%\end{array}$

$0 \%$

$7.1 \%$

$35.7 \%$

$50 \%$

$42.9 \%$

$57.1 \%$

$0 \%$

$0 \%$

\section{AVERAGE \\ $29.12 \%$ \\ $15.33 \%$ \\ $3.28 \%$ \\ $16.42 \%$ \\ $35.71 \%$}

From the above table $35.71 \%$ of the teachers strongly disagreed and $29.12 \%$ strongly agreed with the fact that chemistry teachers utilize instructional materials in teaching chemistry in the schools under study.Meanwhile, the answer to this question is that 'chemistry teachers do not adequately utilize chemistry instructional materials in teaching chemistry in senior secondary schools in Katsina Metropolis

Table 10. Showing responses of both teachers and students on item 13 of the questionnaire

$\begin{array}{lllll}\begin{array}{l}\text { RESPONSE } \\ \text { SD }\end{array} & \text { SA } & \text { A } & \text { U } & \text { DA } \\ \begin{array}{l}\text { FREQUENCY } \\ 0\end{array} & 323 & 2 & 5 & 50 \\ & & & & \\ \begin{array}{l}\text { PERCENTAGE } \\ 0 \%\end{array} & 84.1 \% & 0.52 \% & 1.30 \% & 13.02 \%\end{array}$


From the table above $84.1 \%$ of the respondents strongly agreed and $13.02 \%$ of the respondent disagree with the statement "male chemistry teachers use instructional materials more than the female chemistry teachers". Therefore to answer the research question, Male chemistry teachers utilizes instructional materials in teaching chemistry more than the female chemistry teachers in senior secondary schools of Kastina Metropolis.

This research was tested using inferential statistics (one way ANOVA) with the aid of statistical package for social science (SPSS).

In the first place, data collected using five-point linkert scale such as Strongly agree, SA, Agree A, Undecided, U, Disagree, DA and Strongly disagree, SD; or extremely satisfied, satisfied, neutral, dissatisfied and extremely dissatisfied; is a nominal data. Therefore, for the purpose of this analysis codes are usually given as follows

$\begin{array}{lcc}\text { Strongly agree } & - & 5 \\ \text { Agree } & - & 4 \\ \text { Undecided } & - & 3 \\ \text { Disagree } & - & 2 \\ \text { Strongly disagree - } & 1\end{array}$

Table 11. One Way ANOVA analyses of the mean score SUNCAIS, GSSS K/Kaura and GSSS K/Yandaka on the availability of instructional materials in teaching chemistry 


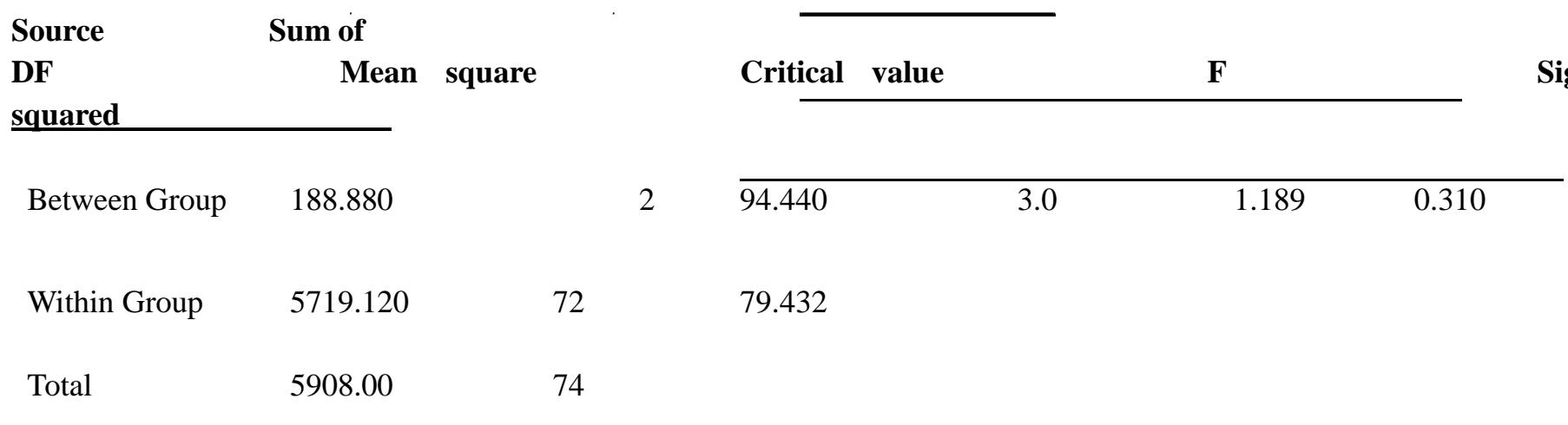

*significant at $\mathrm{p} \leq 0.05$

The result in table above shows that the schools does not differ significantly in the availability of instructional materials. The observed $\mathrm{F}$ value (1.189) in less than the 3.00 for the critical value at

2,72 degree of freedom. The observed $p$ value 0.310 is greater than 0.05 this means that the null hypotheses that there is no significant difference in the availability of chemistry instructional materials in senior secondary schools of Katsina Metropolis is accepted.

Table 12. One Way ANOVA analyses of the mean score SUNCAIS, GSSS K/Kaura and GSSS K/Yandaka on the utilization of instructional material in teaching chemistry

\begin{tabular}{|c|c|c|c|c|c|c|}
\hline Source & $\begin{array}{l}\text { Sum of } \\
\text { square }\end{array}$ & DF & Mean square & $\begin{array}{l}\text { Critical } \\
\text { F-value }\end{array}$ & $\begin{array}{l}\text { Calculated } \\
\text { F-value }\end{array}$ & Sig \\
\hline Between & 133.053 & 2 & 66.527 & 3.0 & 1.985 & 0.027 \\
\hline \multicolumn{7}{|l|}{ Group } \\
\hline Within Group & 12301.220 & 367 & 33.518 & & & \\
\hline$T_{n+n} 1$ & 10121772 & $26 n$ & & & & \\
\hline
\end{tabular}

*significant at $\mathrm{p} \leq 0.05$

The result in table above shows that the schools differ significantly in the utilization of Instructional materials. The observed F value (1.985) in less than the 3.00 for the critical value at

2, 367 degree of freedom. The observed $p$ value 0.027 is less than 0.05 this means that the null hypotheses that there is no significant difference in the utilization of instructional materials in teaching chemistry senior secondary schools of Katsina Metropolis is rejected.

Table 13. Independent sample t-test on the Teachers score in the utilization of instructional materials between male and 
female teachers in teaching chemistry

\begin{tabular}{lcclllll}
\hline \multicolumn{1}{c}{ Pair } & N & Mean & $\begin{array}{c}\text { Mean } \\
\text { Difference }\end{array}$ & $\begin{array}{c}\text { Standard } \\
\text { deviation }\end{array}$ & T & $\begin{array}{c}\text { Degree } \\
\text { of }\end{array}$ & P \\
\hline Male teachers & 7 & 3.57 & 0.429 & 1.618 & 0.612 & 12 & 0.552 \\
$\begin{array}{l}\text { Female } \\
\text { teachers }\end{array}$ & 7 & 3.14 & & 0.900 & & & \\
*significant at $\mathrm{p} \leq 0.05$ & & & & & & \\
\end{tabular}

From the above table it is clear that the $\mathrm{P}$ value (0.552) is greater than 0.05 which signifies there is no significant difference in the utilization of instructional materials in teaching chemistry between male and female chemistry teachers therefore the null hypothesis is accepted.

\subsection{Summary Major Findings}

The following findings emerged from the study that;

1) There is no significant difference in the availability of instructional materials for teaching chemistry in senior secondary schools in Katsina Metropolis due to the fact that the observed $\mathrm{p}$ value 0.310 is greater than 0.05 .

2) There is significant difference in the utilization of instructional materials for teaching chemistry in senior secondary schools in Katsina Metropolis as the observed $\mathrm{p}$ value 0.027 is less than 0.05 .3 ) There is no significant difference in the utilization of instructional materials between male and female teachers of chemistry in senior secondary schools in katsina metropolis as $\mathrm{P}$ value $(0.552)$ is greater than 0.05

4

4

D

i

S

c

u

S
S

i

o

n

o

f

$\mathbf{R}$

e

$\mathbf{s}$

$\mathbf{u}$

l

$\mathbf{t}$

Table 4.1, 4.2 and 4.3 shows that almost all the 25 listed instructional materials are adequately available with the exception of Bunsen burner, watch glasses and graduated cylinders, also from table 4.4 it is clear that the percentage of the available equipment and material in the three schools is $96 \%$, On the other hand, the percent of the unavailable equipment and materials in the three schools is $4 \%$. This indicate that there are instructional materials available for teaching chemistry in senior secondary schools in Katsina Metropolis, This implies that probability of the students of Katsina metropolis performing better is high. From empirical evidence, Edet (2008) in his study the result showed that students taught using laboratory facilities frequently achieved higher than those taught without utilizing laboratory facilities during Biology lessons.

Table 4.5 and Table 4.6 shows that teachers of chemistry do not utilize instructional materials, as majority of the students $(64.89 \%)$ strongly disagreed and $24.42 \%$ 
disagreed with the fact that chemistry teachers adequately utilize instructional materials in teaching chemistry in the schools under study while on the hand $35.71 \%$ of the teachers strongly disagreed and $29.12 \%$ strongly agreed with the fact that chemistry teachers utilize instructional materials in teaching chemistry in the schools under study. This indicate that despite the availability of instructional materials, teachers of chemistry do not adequately utilized them. This is in line with Uyagu (2009) which revealed that students performed better when appropriate and improvised materials were made available and utilized in teaching science.

Table 4.7 shows that male chemistry teachers utilizes instructional materials in teaching chemistry more than the female chemistry teachers in senior secondary schools of Kastina Metropolis. Due to the fact $84.1 \%$ of the respondents strongly agreed and $13.02 \%$ of the respondent disagree with the statement "male chemistry teachers use instructional materials more than the female chemistry teachers".

Table 4.8 shows schools does not differ significantly in the availability of instructional materials for teaching chemistry in senior secondary school in Katsina metropolis, since observed $p$ value 0.310 is greater than 0.05 . while Table 4.9 shows that the schools differs significantly in the utilization of instructional for teaching chemistry in senior secondary schools in Katsina metropolis since the observed $\mathrm{p}$ value 0.027 is less than 0.05 . Thus implies that despite the availability of the instructional materials chemistry teachers do not adequately utilize them. This finding is in line with that of Opara (2008) which revealed that laboratory facilities were not utilized during chemistry teaching and learning.

Table 4.10 shows that there is no significant difference in the utilization of instructional materials between male and female teachers of chemistry in senior secondary school in Katsina Metropolis, from the table it is clear that the $\mathrm{P}$ value (0.552) is greater than 0.05 .

\section{CONCLUSION AND RECOMMENDATION}

\subsection{Conclusion}

From the findings of the study, it can be concluded that utilization of instructional materials have influence in teaching chemistry in senior secondary schools in Katsina metropolis and that there are instructional materials available for teaching chemistry. Also, based on the finding, it can be inferred that chemistry teachers do not use instructional materials in teaching chemistry in senior secondary schools in Katsina metropolis.

\subsection{Recommendations}

Based on the findings of this research, the following recommendations were made:

1. Adequate instructional materials for the teaching of chemistry in senior secondary schools in Katsina metropolis should be provided by the ministry of education and school management.

2. Teachers should improvise where instructional materials are not available to teach chemistry in the senior secondary schools in Katsina metropolis.

3. Utilization of instructional materials should be encourage at all levels of education.

4. Teacher education programme should integrate materials development whereby teachers learn how to design and construct various materials and equipment which could be used for teaching- learning process.

5. Resource centres should be created in each Education zone where teachers can go to borrow teaching materials or take their students there to use the materials.

\section{REFERENCES}

[1] Abdullahi, T. (2004). Teaching facilities and students' performance in chemistry. A case study of Secondary school students in Zaria M.Ed thesis, A.B.U, Zaria.

[2] Abdu-Raheem, B. O. (2014). Improvisation of instructional materials for teaching and learning In secondary schools as predictor of high academic standard. Nigerian Journal of SocialStudies, vol(17).No(1).

[3] Abdu-Raheem, B. O. (2016). Effects of instructional materials on Secondary Schools students'academic achievement in Social Studies in Ekiti State. World Journal of Education, vol (6).No (1).

[4] Abiodun-Oyebanji, O., \& Adu, E.T. (2007). Principals' performance in instructional supervision In the use of resources in senior secondary schools in Ekiti State. Journal of Educational Focus, Vol. (1 No.(1).

[5] Agina-Obu, T.N. (2005). The relevance of instructional materials in teaching and learning. Ajayi, Y.A. (2000). A guide for effective teaching. Lagos: IDEMAC Nigeria Ltd.

[6] Akinsola, M. K and Igwe, I. O. (2002). The relative effects of Meta cognitive strategy of framing On students' achievement 
in selected difficult chemistry concept, Journal of Science Teachers Association of Nigeria, 37, (1 \& 3), 20 - 28.

[7] Amaefule, A. A. (2001). Chemistry Education as a basis for Technological Development: Gombe Technical Education Journal, 3, 63-75.

[8] The ASSURE Model: Creating the Learning Experience." The ASSURE Model: Creating The Learning Experience. Pearson,n.d. Retrieved 09 july 2017 http://wps.prenhall.com/chet_smaldino_instruct_9/67/17197/ 4402563.cw/index.html

[9] Edet, U. B. (2008). Effect of environmental resources on students' academic performance in

[10] Biology. $49^{\text {th }}$ annual conference of Science Teachers' Association of Nigeria.

[11] Esu, A.E.O., Enukoha, O.I.T., \& Umorem, G. U. (2004). Curriculum development in Nigeria for Colleges and universities. Owerri: Whyte and Whyte Publishers.

[12] Fadeiye, J.O. (2005). A social studies textbook for colleges and universities. Ibadan: Akin Johnson Press and Publishers.

[13] Federal Republic of Nigeria (2004). National Policy on Education. Lagos: Heinemann Educational books Ltd.

[14] George, G. O. (2008). Causes of Poor Achievement in WAEC Biology Examinations in Taraba State Secondary Schools. International Journal of Life Sciences and Technology 21 (3).

[15] Ibrahim, S.A. (2000). Instructional Materials. Journal-Teachers Periscope of NUT, Kogi State Wing, Vol. 1. (2), 27-29.

[16] Ikerionwu, J.C. (2000). Importance of aids and resources in classroom teaching. Knirk \& Gustafson Instructional Design model. (n.d.). Retrieved July 18, 2017, from http://lts.ncsu.edu/guides/instructional_design/selecting_mod els2.htm

[17] Kochhar, S. K. (2012). The teaching of social studies. New Delhi, India. Sterling Publishers Private Limited.

[18] Maduekwe, A. N. (2006). Perspective on Teacher Education and ICTs in the Language Classroom, V. B. (ed). An Introduction to Educational Technologies in Education Lagos: Sibon books Ltd.

[19] Mba, T. N. (2004): Adult education and development. Port Harcourt: Pearl Publisher. Mberekpe Augustine, Chukwunyeremunwa. (2013) Effect of students improvised instructional Materials on senior secondary school students' achievement in biology. University of Nigeria Nsukka.

[20] NERDC, (2009). Workshop on Difficult Concepts Biology Group report. Nigeria Educational Research and Development Council Lagos.

[21] Nwagbo, C.R. (2006). Effects of two teaching methods on achievement and Attitude to Biology Of Students of different levels of scientific literacy. International Journal of Educational Research. Retrieved from www.elsevier.com/locate/ijdures. On 13th April 2017.

[22] Nzewi,U. M, and Nwosu, A. A. (2009). Course Guide, EDU 236: Biology Methods. National Open University of Nigeria.
[23] Ojokuku, O.G. (2012). Understanding Chemistry, Zaria:MacChin multimedia Designers, Press On Chem resources.

[24] Ojokuku, O.G. (2001). Practical Chemistry, for schools and colleges. Ibadan: Gbabeks Publishers Ltd.

[25] Oladipo, F.O. (2001). Introduction to Agricultural Journalism and audio-visual methods. Ilorin: KWCOED, Ilorin.

[26] Olumorin, C. O., Yusuf, A., Ajidagba, U. A., \& Jekayinfa, A. A. (2010). Development of Instructional materials from local resources for art-based courses. Asian Journal of Information Technology, Vol. $\quad$ (9) No http://dx.doi.org/10.3923/ajit.2010.107.110.

[27] Oluwagbohunmi, M.F., \& Abdu-Raheem, B.O. (2014). Sandwich undergraduates' problem of Improvisation of instructional materials in social studies: The case of Ekiti State University

[28] Opara, M. F. (2008). Utilization of laboratory facilities and students' academic performance Unpublished M.Ed. thesis of Anambra State University, Nigeria.

[29] Uyagu, B.G. (2009) Effects of Instructional Materials Usage and Teachers' Quality on Students Performance in Science in Senior Secondary Schools in Zaria LGA of Kaduna State. Unpublished M.Ed. Thesis, A.B.U. Zaria - Nigeria. 